All Correspondence this week arises from recent News and Editorial coverage of fraud and quality control.

\section{Why negatives should be viewed as positives}

\section{SIR - Your News story “Journals submit} to scrutiny of their peer-review process" (Nature 439, 252; 2006) reports findings of no bias against manuscripts presenting negative results. But the journals examined in this study are at the top of their field, and top journals are only likely to receive submissions reporting negative results if these are of clear 'positive' interest. This is certainly the case in ecology: Julia Koricheva (Oikos 102, $397-401$; 2003) showed that non-significant results in ecology tend to be published in lower-impact journals.

This filtering of results undoubtedly biases the information available to scientists (see, for example "Null and void" Nature 422, $554-555 ; 2003)$. And communication is at the heart of science.

If non-significant results remain unpublished, we will be left with only half the picture. We encourage scientists to submit the negative results of their rigorous research to journals such as the Journal of Negative Results - Ecology and Evolutionary Biology (www.jnr-eeb.org), the Journal of Negative Results in BioMedicine (www. jnrbm.com), the Journal of Negative Observations in Genetic Oncology (www. path.jhu.edu/NOGO), and the Journal of Negative Results in Speech and Audio Sciences (journal.speech.cs.cmu.edu).

Bob O'Hara ${ }^{\star}$, Mike S. Fowlert,

Christine A. Johns ont,

*Department of Mathematics and Statistics, PO Box 68 (Gustaf Hällstrōmin katu 2b), FIN-00014, University of Helsinki, Finland †Department of Biological and Ervironmental Sciences, PO Box 65 (Viikinkaari 1), FIN-00014, University of Helsinki, Finland

$\ddagger$ Evolution, Ecology and Organismal Biology, Ohio State University, 314 Aronoff Laboratory, 318 West 12thStreet, Columbus, Ohio 43210, USA

\section{A simple system of checks and balances to cut fraud}

SIR - As your Editorial "Standards for papers on doning" (Nature 439, 243; 2006) demonstrates, the fraudulent Hwang stem-cell research papers will have consequences for future research in this and related biomedical fields. As you point out, this does not justify imposing more rigorous standards for reviewing manuscripts in this field than others. Enforcing the deposition of samples with independent laboratories or repositories would be inappropriate, and deposition could also be done fraudulently. Although deposition might allow another layer of supervision, it would also create another layer of complexity and cost to stymie further research in a field already encumbered by restrictions.

As researchers in different parts of this field, we would like to make a joint response. We believe a simpler system of checks and balances could reduce incidents of scientific fraud and increase our confidence in published reports.

First, all co-authors should indicate the scope of their involvement and declare their understanding of the data in, for example, an author contribution statement such as that recommended by Nature (www.nature.com/ nature/authors/gta). Surprisingly, it seems clear in retrospect that many of the 26 authors on Hwang's report (Science 308, 1777-1783; 2005), could not have attested to the veracity of the human nuclear-transfer embryonic stem cells (ntESC) presented. A requirement for personal accountability might have encouraged greater communication between authors and uncovered the deception before publication.

Second, all journals should, like Nature (www.nature.com/nature/authors/policy), require that all published reagents and cell lines be made available to other laboratories.

Finally, peer reviewers should be encouraged to demand that authors provide clear and strong evidence that the data presented support the claims made including the request for mitochondrial DNA fingerprints if appropriate.

Of course, the best way to ensure integrity in any field is independent replication of results, which requires multiple investigators to be free to do the research. Current limits on US federal funding make independent verification of results especially challenging in the case of human ESC or ntESC research, and undoubtedly contributed to the difficulties in uncovering the misconduct of Hwang and his colleagues .

Xiangzhong Yang

Center for Regenerative Biology, University of

Connecticut, 1392 Starrs Road Unit 4243,

Starrs, Connecticut 06269-4243, USA

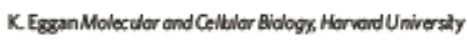

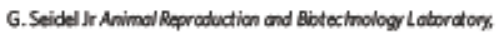

Colonodo Stete University

R. Jaenisch Department of Eliologx, Mossechusetts institute of Technology

D. Metan Malecular and Collubr Blologx, Haverd Uhiversity

\section{Peer review could be improved by market forces}

SIR - Although peer review seems the best system for quality control of scientific publications and grant proposals ( ${ }^{\circ} \mathrm{Three}$ cheers for peers ${ }^{x}$ Nature 439,$118 ; 2006$ ), we might try to improve it. Market forces are known to optimize complex systems where multiple players have conflicting interests. Economic principles and internet technology could be applied to a peer-review system in the following way. First, a central digital repository receives a paper for a fee ' $\mathrm{x}$ '. Potential referees then bid to review the paper, and, if approved by the author, receive a fee ' $y<x$.' Payments are made at the end of each month, allowing for exchanges where an author pays by reviewing other papers.

Referees who can recommend an appropriate journal for the paper and provide the required reference are given due credit and might eventually raise their fee. Authors wanting additional improvements to their work might also pay a higher fee.

Soon, an active exchange could take off where referees quote their position in the peer-market as eagerly as authors quote their citation impact. This system could diminish the workload of referees, by reducing the need to review the same paper for different journals. Eventually this system might be run as an independent peer-review exchange for a profit.

Klaus Jaffe

Laboratorio de Comportamiento, Universidad Simón Bolivar, Apartado 89000 , Caracas 1080, Venezuela

\section{Bureaucracy won't change the character of a cheat}

SIR - Your Editorial "Standards for papers on cloning" (Nature 439, 243; 2006) invites comment on current peer-review procedures and fraud detection. The use of deception for personal gain is neither new nor restricted to human beings. To my mind, the three relevant new things in contemporary society are intense media attention, piles of bureaucracy through which even the lowestranking staffhave to wade and a culture dominated bylawsuits where redirecting blame seems increasingly prevalent.

During my undergraduate studies, the idea of reporting fictitious data never crossed $\mathrm{my}$ mind. And yet I witnessed friends regularly 'massaging' graphs, in spite of being taught the proper scientific technique. Is this not, therefore, a problem rooted in personal character? Would the introduction of yet more bureaucracy really solve the problem?

Science and fraud have coexisted for millennia, throughout which time progress was made without computers or armies of administrators. In the case of Hwang and, more recently, Jon Sudbø - who invented test subjects and published his results in The Lancet (Nature 439, 248-249; 2006) the open scientific process of peer review, publication and further study revealed the falsehood, and the only people who should be held accountable are those committing the 